\title{
The Shift of the Policy Towards FDI in European Union: Determinants and Challenges
}

The Shift of the Policy Towards FDI in European Union: Determinants and Challenges

Submitted 06/2020

\section{Aleksandra Borowicz}

Faculty of Economics, University of Gdansk

Accepted for

publication $07 / 2020$

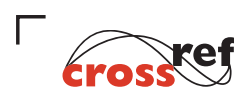

http://dx.doi.org/10.5755/j01.eis.1.14.27556

Since 2016, a change in the policy on foreign direct investment (FDI) can be observed in the European Union. This change was significantly influenced by global processes, which resulted in a particular interest in direct investments carried out by transnational corporations from China, India or Russia. In particular, countries such as France, Germany and the United Kingdom, observed a significant increase in the number of mergers and acquisitions of domestic enterprises in 2010-2016. Therefore, in 2018 the process of creating a European Screening Mechanism was initiated, which entered into force in March 2019. At the same time, at the end of 2019, the outbreak of a COVID-19 virus pandemic stopped the process of further globalization by breaking global supply chains, and by restricting the flow of goods, people and capital.

KEYWORDS: FDI, screening mechanism, European Union, globalization, COVID-19.

The European Union has always been at the centre of investors' attention in terms of investing capital. The entry of foreign capital from a third country in the form of FDI means free access to the common market, i.e. employees, technologies, know-how but also enterprises. Therefore, foreign capital seeks to enter the European market in order to be able to benefit from the absorption of resource. On the other hand, the progressing globalization, and in particular the development of technology and information, significantly influenced the growing interest of countries in the inflow of investments in the form of FDI. Regional economic integration was conducive to capital integration, and incoming FDI began to be seen as a significant benefit for the host economy.

Regardless, globalization seems to have peaked in recent years. UNCTAD calls the period of recent years the "slowbalization" period. The term is currently widely used to depict the meaning the period when globalization loses its dynamics, which was observed in the scope of foreign direct investment, portfolio investment or trade. All these elements began to shrink in relation to their share in GDP. Growing tension, and even trade war on the US-China line, are adding more pieces to the puzzle. Staring from 2016 World Investment Report underlined that FDI lost its momentum. The rate of the expand of the international production by Multinational Entities (MNEs) has slowed down (WIR, 2017). Some of the experts declare that the world economy shall forget about globalisation and slowbalization will strongly arise from regional integration and globalisation (Kapellian, 2020).

The turn of 2019/2020 is the last factor that changes the global situation, because of the pandemic outbreak. The emergence of a global pandemic, which significantly affected the functioning of the global economy, meant that economic relations, and including the area of FDI, will no longer be the same. UNCTAD reported in March 2020 that FDI flows in 2020-2021 will be reduced

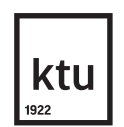

European Integration Studies No. 14 / 2020, pp. 117-124 doi.org/10.5755/j01.eis.1.14.27556 
by $30-40 \%$ instead of $5-15 \%$ as reported at the beginning. Transnational corporations felt a drop in sales, and were forced to revise their financial forecasts. The industries that are hit hardest were: the raw materials industry', airlines, and the automotive industry (UNCTAD 2020).

The purpose of the article is to identify and describe the factors that significantly influenced changes in the European Union's policy towards foreign direct investment, and to discuss these changes. The article will analyse the phenomenon of foreign direct investment in the $E U$ in recent years. The observed inflow of FDI to the EU caused a specific reactions in each of member states, which will be discussed in this article. The second topic to be analysed will be possible consequences of the outbreak of COVID-19 in the area of EU policy. This article falls within the recent research trend on foreign direct investment, in the context of the changing global environment as a result of a pandemic. What's more, the article may bring new voice to discussion in the area of policies towards FDI, formulated by countries and the European Union during the period of return to growth and building economic resilience to shocks. The research methods used in this article are analysis of statistical data to, and analysis of official documents related to the policy of the European Union in the field of foreign direct investment.

\section{Why foreign direct investment are important?}

Foreign direct investment has a significant impact on the host country's equipment in the area of production, in particular: capital, technology and employment (Salamaga 2013, 22; Lehnert, Benmamoun, Zhao 2013; Brenton et al. 2001). Research highlights the positive impact of FDI on European economies in the form of new technologies, market access, job creation or wage increases. The extent of this impact depends on the absorption capacity of the economy (Blomström, Kokko 1998, 247 -277; Crespo, Fontoura 2007; Dachs, Betina 2014, 214-232). Research on the relationship between mergers and acquisitions and the value of exports has shown that FDI complements and supports host country exports (Carril-Caccia, Pavlova: 2018). Umiński (2002) indicates the occurrence of so-called indirect effects, that consist of improving the quality and the modernisation of used techniques, through the process of learning to modify, adapt and develop technologies. In addition, transnational corporations play an important role in regional and local economies. M. Forsgren (2008) listed the following roles: dominant entity, coordinating entity, entity creating and sharing knowledge / technology and the international networks. On a national scale, FDI stimulates GDP (Woźniak 2008; Anyamele 2010; Abbas et.al 2011) as well as employment (Rozen-Bakchner 2017; Estrin 2017; Jude \& Silaghi 2016).

Why did the European Union introduce the FDI screening mechanism?
In 2016 and 2018, two controversial events took place on the German market, that were related to attempts of taking over companies by Chinese investors. Germany blocked the second transaction regarding the transmission company. However, the transaction regarding KUKA AG, which was taken over by Midea, has been finalized. At the end of July 2018, Germany blocked the acquisition (Catrain\&Theodoropoulou 2019: 1-2).

Global foreign foreign investment has fallen to $\$ 1.4$ billion in 2018. What's more, this decline has been visible since 2015. However, the European Union remains at the forefront of both inward and outward FDI stocks. In 2018, it recorded 31.3\% and 37.1\% share in global FDI. However, it should be mentioned that this share fell from around $50 \%$ in the early $1990 \mathrm{~s}^{2}$. According to data of EUROSTAT in 2018 the inflow of FDI came in over 25\% from U.S.; 18,9\% from Great Britain, and $10 \%$ from Switzerland. China stood for only 2,8\%.

In recent years in the European Union, on the initiative of Italy, France or Great Britain started

1 This effect has been enlarged by the plunge of prices on the oil market in March 2020.

2 Own study based on UNCTAD data accessed on 16.07.2019 and World Investment Report 2019. 
a discussion on the inflow of foreign investments from third countries. Although only $0.4 \%$ of enterprises in the EU are controlled by capital from third countries, they generate around $6 \%$ of employment and $11 \%$ of value added. In the global economy, a trend has been observed associated with the growing role of FDI inbound developing economies, but also such as Russia and China. In this case, the increasing involvement of capital from these regions in the European Union is particularly visible. The involvement of Chinese capital in the form of FDI in the years 2010-2016 increased 15-fold in the EU (Hanemann, Huotari, Kratz 2019). Despite the fact, that the share constitutes about $2 \%$ of incoming FDI (compared to $40 \%$ share of the USA), this does not change the fact that the degree of Chinese capital penetration in the European Union is growing dynamically (Bickenbach, Liu 2018, 15-22). At the same time it must be mentioned that this penetration is unequal between MS. The following countries: France, Germany, Great Britain, The Netherlands, Italy and Sweden in 2016 stood for 76\% of M\&A's in European, whereas the rest of 22 MS represented 24\% (Bourgeois 2018, 35).

Nevertheless the key problem for EC was not only the dynamics of engagement of Chinese investors on European market. The rules of the game considering the role of the state in the process of aquring the european companies is questioned by EC. Research carried out for the European Commission in the process of preparing the legal framework for tools controlling the inflow of FDI from third countries indicates that enterprises controlled by foreign capital from outside the EU have a significant share in assets. In 2016, the surveyed enterprises that were capitally dependent on companies from third countries accounted for only $2.8 \%$, but represented approx. $35 \%$ of the assets of the surveyed enterprises. Only $9.3 \%$ of enterprises with foreign capital are listed on stock exchanges. As much as $45 \%$ of the assets of listed companies belonged to companies controlled by capital from third countries, which shows that these companies are relatively larger than European companies. Greenfield investments focused in the following industries in 2017 (EC 2019):

- pharmaceutical and chemical

- electronics, electronic equipment and machinery

- motor vehicles and transport equipment

- gas and electricity

- computers and IT services

- financial and insurance services.

European Commission pointed out the role of the state-owned companies has risen. Fristly, as the entities undertaking standing behind the FDI, but also as a target of third countries investors. The risk that arises form this context is closely connected with the threat of acquiring and controlling critical technologies, infrastructure or sensitive information. It brings a challenge for securing the public order (EC, 2017).

The idea that the European Commission promoted in the context of work on the control mechanism of the FDI entering Poland has two dimensions. Firstly, the European Union has sought, and continues to follow the course to ensure equal access for investors from third countries to the common European market. Secondly, to introduce such a mechanism that will allow observing and verifying the actions of investors in the common market. The European Union has clearly indicated that it is open, and interested, in the inflow of FDI from third countries, but not at all costs. This process is to serve socio-economic development in the EU, and not pose a threat to public security and order (EC 2017, p. 5). In particular, the European Commission drew attention

What is FDl Screening Mechanisms? 
to the situation when FDI is carried out by enterprises financed from public funds or directly state enterprises, which significantly affects the creation of unequal conditions of competition.

The FDI screening mechanism came into force in 2019. Earlier analysis revealed that 12 out of 28 Member States had a mechanism for monitoring incoming FDIs. EC pointed out, that in march 2020, already 14 countries were using screening mechanism (EC 2020). Most frequently, Member States used provisions for sectors considered strategic, as energy or telecommunications, but there were also provisions with a more horizontal wording, related to maintaining security and public order. The criteria applied refer to both qualitative criteria related to obtaining control over the acquired company, and quantitative criteria related to shares or the number of votes (EC 2017). The tools used by the Member States are perceived as a manifestation of the restriction on the free movement of capital and freedom of entrepreneurship, as they also involve investors from European Union countries (art. 49 and art. 63 TFEU). At the same time, the laws ensuring security and public order in member states justify the solutions undertaken at the level of individual countries. This is also provided for in the Treaty, which furthermore allows for taking into account proper justification and equal treatment of investors ${ }^{3}$. Thus, they were found to comply with the principles of proportionality of law.

The concept finally presented by the European Commission is significantly different from the provisions in individual Member States. The European Commission has clearly indicated that the operation of this mechanism is to be based on cooperation and exchange of information between Member States. Furthermore, areas that the EU has identified as being of strategic importance, mainly relate to those ensuring security and public order, in particular research in technologically intensive spheres under Horizon 2020, space (GALILEO) or trans-European networks (TENs).

The mechanism itself consists of several tools that can be used by the European Commission or Member States (Cremona 2018: 60):

- Monitoring by the European Commission of incoming FDI, and in particular investments directed to sectors of strategic importance for security and public order, implemented by enterprises controlled by capital from third countries.

- Coordination of the exchange of information between Member States on the situation in the area of ZIB.

- Adapting these regulations to the legal order at Member State level.

- Screening of FDI by the European Commission in a situation where foreign investment may significantly affect European programs and projects.

Although it seems that the European Commission is taking over the competences of the Member States or its actions overlap with the competences of the Member States, Art. 65 paragraph 1 point b TFEU clearly indicates the specific scope of situations where Member States may impose restrictions (TFEU, 2012).

\section{New challenges European Union faces in the area of foreign direct investment}

Undoubtedly, the European Union's activities in the field of domestic market protection were justified. The growing involvement of Chinese, Russian or Indian capital in European companies and their acquisition in recent years has meant that the EU could not passively watch this phenomenon. The more that a significant part of the Member States had mechanisms for monitoring FDI. For example, in July 2015, the "Act on control of certain investments" came into force in Poland, which provides, first of all, for ex-post control of investors, and secondly, it seems to be

3 See more: article 49 and 63 of Treaty on Functioning of European Union. 
insufficient, as it does not apply to foreign investors and generally. Some sources indicate that the role of the Office for Competition and Consumer Protection (UOKiK), which could monitor investments being carried out in Poland, should be strengthened (Izdebski et al., 2016: 30-31). The Regulation of the Council of Ministers in issued 3.12.18 supplements these activities, which indicates the list of protected companies. They come from the chemical, telecommunications and energy industries (( Dz.U. 31.12.2018, poz. 2524)

Since 2019, more than 35 investments have been notified in the European Union. However, it is now crucial to change the approach to foreign direct investment in the context of the ubiquitous coronavirus pandemic. As previously mentioned, a change in the face of globalization will be of significant importance for further activities in the area of FDI policy. On the one hand, it will face a situation in which the largest enterprises will be weakened and may become the target of acquisitions of enterprises supported by third-country governments. On the other hand, the European economy will suffer from a pandemic. Forecasts predict a contraction in GDP throughout. Preliminary estimates forecast that the first quarter of 2020 in the entire EU will end with a reduced GDP of $-2.7 \%$ compared to the previous year's quarter (table below).

\begin{tabular}{|l|c|c|c|c|c|c|c|c|}
\hline & \multicolumn{3}{|c|}{$\begin{array}{c}\text { Percentage change compared with the } \\
\text { previous quarter }\end{array}$} & \multicolumn{3}{c}{$\begin{array}{c}\text { Percentage change compared with the same } \\
\text { quarter of the previous year }\end{array}$} \\
\hline & $2019 Q 2$ & $2019 Q 3$ & $2019 Q 4$ & $2020 Q 1$ & $2019 Q 2$ & $2019 Q 3$ & $2019 Q 4$ & $2020 Q 1$ \\
\hline Euro Area & 0.1 & 0.3 & 0.1 & -3.8 & 1.2 & 1.3 & 1.0 & -3.3 \\
\hline EU & 0.2 & 0.4 & 0.2 & -3.5 & 1.5 & 1.6 & 1.3 & -2.7 \\
\hline
\end{tabular}

Source: Eurostat, Preliminary flash estimate for the first quarter of 2020, https://ec.europa.eu/eurostat/ documents/2995521/10294708/2-30042020-BP-EN.pdf/526405c5-289c-30f5-068a-d907b7d663e6 retrieved: 01.06.2020

Policy towards foreign investment will be one of the key elements in rebuilding the European economy. Currently, changes have been made to the provisions for foreign investors in the European Commission document "Communication from the Commission Guidance to the Member States concerning foreign direct investment and free movement of capital from third countries, and the protection of Europe's strategic assets, ahead of the application of Regulation (EU) 2019/452 (FDI Screening Regulation) 2020 / C 99 I / 01." The issue of guidelines for Member States points precisely to the health sector, which is particularly important for the safety and health of EU citizens in the face of a pandemic. What's more, the message indicates that in transactions involving FDI, one should depart from quantitative approaches to investment assessment, because at the initial stage of development of start-up companies this value may be limited, but the technology and research that FDI affects may be strategic. Furthermore, the regulation setting out the framework for monitoring FDI is extended to all sectors.

The outbreak of the COVID-19 pandemic has reinforced the ongoing phenomena of policy towards foreign investors in the EU. On the one hand, support for the inflow of capital that is desired in the European Union in the face of the economic slowdown. On the other hand, seeking to rebuild economic resilience to possible economic shocks creates a wave of protectionism. Due to the fact that Member States are very diverse in terms of incoming FDI, this should be particularly cautious. Countries such as Germany, France and Italy are exposed to dynamic capital penetration from third countries. This applies not only to companies of strategic importance, but also to stable enterprises, important for regional communities in terms of employment or cooperation with suppliers in a given location. In this context, the position of Central and Eastern European
Table 1

Growth rates of GDP in volume (based on seasonally adjusted data)

\section{Pandemic context to policy towards FDI in European Union}


countries whose economies still rely on capital inflows in the form of FDI should also be taken into account. The slowdown in the area of foreign investment may result in the emergence of pressure and competition race to attract foreign investment.

To sum up, there are several important elements that give a new context and impose a number of challenges in the area of policy towards foreign investors in the European Union:

The European Union should continue to monitor the inflow of foreign investment from third countries in order to be able to react on an ongoing basis in situations where it is taking place in strategic and technologically intensive sectors.

The legal framework related to FDI monitoring in the health sector should become a key element of policies towards foreign investors at Member State level due to the prevailing pandemic.

The European Commission and the Member States should be cautious about foreign investors, because in the process of rebuilding economies, foreign capital, especially for Central and Eastern European economies, is still an important element in the context of job creation, technology flow and foreign trade. So the protectionism is not an answer for the global slowdown.

Limited global flows of foreign direct investment will exert pressure in the process of competing for FDI in countries that have hitherto been attractive in terms of investment placement.

At the same time the ongoing monitoring will create a framework for policy makers to be vigilant for third countries behaviour. Already it is witnessed that after 2016 the dynamics of M\&A's by Chinese investors decreased. The actions undertaken by EU brought raised awareness on the MS level.

Due to interrupted global supply chains, foreign investment will be relocated to the European Union, especially in countries open to foreign investors.

The European Union's actions in the area of policy reorientation towards foreign investors are not new on the global stage. Countries such as the USA, Canada and Australia have for many years had a legal framework for controlling FDI in their economies. Due to the complicated legal system in the European Union, the tools proposed by the European Commission are based on cooperation and exchange of information. The emphasis is on the fact that the entry of a foreign investor into one Member State results in unrestricted access to the European common market. Thus, the observed growing number of mergers and acquisitions in the European Union since 2010 has resulted in the adoption of a mechanism for monitoring FDI from third countries in 2019. The reasons for that was rising role of FDI in the form of M\&A which in 2010-2016 were highly concentrated in six countries: France, Germany, Italy, The Netherlands, Sweden and Great Britain. The undertaken discussion within EU initiated in 2016 resulted in the rise of the awareness on MS level.

FDI screening mechanism can be considered as a moderate form of protectionism, which focus on the support of countries to prevent from predator investments based on utilization of stateowned entities and focused on the access to key assets and technologies from the EU perspective. The outbreak of pandemic in 2020 it gives a new context. Especially the sector of broadly understood as health, shall be protected to support the public safety and public order in time of unforeseen shocks. Independence of EU and its MS in this area will significantly affect the vulnerability of economy and society to shocks.

The turn of 2019 and 2020 has identified several new challenges facing the European Union as a whole and each Member State. The spectre of economic slowdown, redefining globalization in favour of deepened regional economic integration, interrupted global supply chains contribute to a change in thinking about foreign direct investment. Affected weak industries need protection against uncompetitive takeover practices by state-owned companies from third countries. Strong enterprises will need recapitalization to rebuild their potential. A particularly interesting 
issue will be the strategy of EU countries which have been actively competing for foreign direct investment such as Poland, the Czech Republic and Hungary so far. The screening mechanism towards FDI in this changing global surrounding will strongly influence the shift in the transmission channels of FDI, which will differ in selected countries. This direction shall be taken into consideration in further research.

Abbas Q., Akbar S., Nasir A.S., Ullah H.A., Naseem M.A. 2011. "Impact of Foreign Direct Investment on Gross Domestic Product". Global Journal of Management and Business Research, Vol. 11 Issue 8. https:// globaljournals.org/GJMBR_Volume11/5-Impact-of-Foreign-Direct-Investment-on-Gross-Domestic-Product.pdf

Anyamele O.D., 2010. Foreign Direct investment, Exports, and Education on Economic Growth in Sub-Saharan African, "International Research Journal of Finance and Economics", Issue 51.

Bickenbach F.\& Wan-Hsin L. 2018. Chinese Direct Investment in Europe - Challenges for EU FDI Policy, CESifo Forum, ifo Institut - Leibniz-Institut für Wirtschaftsforschung an der Universität München, Vol. 19, Iss. 4, pp. 15-22. https://www.econstor.eu/bitstream/10419/199017/1/CESifo-Forum-2018-4-p15-22.pdf , [accessed on: 01.11.2019]

Blomstrom M., Kokko A. 1998. "Multinational Corporations and Spillovers". Journal of Economic Surveys, 12(3), 247-277. doi:10.1111/1467-6419.00056 https:// doi.org/10.1111/1467-6419.00056

Bourgeois J.H.J, EU Framework for Foreign Direct Investment Control, Wolters Kluwer, 2018.

Brenton P., DiMauro, F., Lücke, M. 2001. Economic integration and FDI: an empirical analysis of foreign investment in the EU and in Central and Eastern Europe, Phare ACE Programme Discussion Paper Series, No. 09/1, ACE Programme Management, Brüssel

Carril-Caccia Federico\&Pavlova Elena. 2018. "Foreign direct investment and its drivers: a global and EU perspective". ECB Economic Bulletin, Issue 4/2018. https://www.ecb.europa.eu/pub/economic-bulletin/articles/2018/html/ecb.ebart201804_01. en.html\#toc2, [accessed on: 30.10.2019]

Catrain L., Theodoropoulou E. 2019. "EU overview" in: Goldman C.S.\& Koch M. (eds.), The Foreign Investment Regulation Review, 7th edition, The Law Review, UK.

Cremona M. 2018. "Regulating FDI in EU. Legal Framework" in: Bourgeois J.H.J. (ed.) EU Framework for Foreign Direct Investment Control, Wolters Kluwer, 2018.
Crespo N., Fontoura, M. P. 2007. Determinant Factors of References FDI Spillovers - What Do We Really Know? World Development, 35(3), 410-425. https://doi.org/10.1016/j. worlddev.2006.04.001

Dachs Bernhard\& Peters Betina. 2014. "Innovation, employment growth, and foreign ownership of firms. A European Perspective". Research Policy, 43(1), 214-232. doi:10.1016/j.respol.2013.08.001 https://doi.org/10.1016/j.respol.2013.08.001

Dz.U. 31.12.2018. Poz. 2524. Rozporządzenie Rady Ministrów z dnia 27 grudnia 2018 roku w sprawie wykazu podmiotów podlegających ochronie. http://prawo.sejm.gov.pl/isap.nsf/download.xsp/ WDU20180002524/0/D20182524.pdf [retrieved on: 15.05.2020]

EC. 2020. Communication from the Commission Guidance to the Member States concerning foreign direct investment and free movement of capital from third countries, and the protection of Europe's strategic assets, ahead of the application of Regulation (EU) 2019/452 (FDI Screening Regulation) 2020/C 99 I/01. https://eur-lex.europa.eu/legal-content/ GA/TXT/?uri=CELEX:52020XC0326(03) [retrieved on: 02.06.2020]

EC.2019 (a). List of screening mechanisms notified by Member States. [rertieved on: 12.05.2020] https:// trade.ec.europa.eu/doclib/docs/2019/june/tradoc_157946.pdf

EC. 2019 (b). Commission Staff Working Document on Foreign Direct Investment in the EU Following up on the Commission Communication "Welcoming Foreign Direct Investment while Protecting Essential Interests". SWD(2019) 108 final, 3. https:// trade.ec.europa.eu/doclib/docs/2019/march/tradoc_157724.pdf, [retrieved on: 8.11.2019]

EC. 2017. Welcoming Foreign Direct Investment while Protecting Essential Interests. COM(2017) 494 final. https://eur-lex.europa.eu/LexUriServ/LexUriServ.do?uri=COM:2017:0494:FIN:EN:PDF , [retrieved on: 01.11.2019]

Estrin S.2017. "Foreign direct investment and employment in transition economies. Has FDI into transition 
countries had the expected economic effects?". IZA World of Labor 2017: 330, doi: 10.15185/izawol.330 https://doi.org/10.15185/izawol.330

Eurostat, Preliminary flash estimate for the first quarter of 2020, https://ec.europa.eu/eurostat/documents/2995521/10294708/2-30042020-BP-EN. pdf/526405c5-289c-30f5-068a-d907b7d663e6 [retrieved: 01.06.2020]

Forsgren M. 2008. Theories of the Multinational Firm". A Multidimensional Creature in the Global Economy", Edward Elgar, Cheltenham UK, Northampton, MA, USA

Thilo, Huotari Mikko, Kratz Agatha. 2019. "CHINESE FDI IN EUROPE: 2018 TRENDS AND IMPACT OF NEW SCREENING POLICIES". MERICS Papers on China. https://www.merics.org/sites/default/ files/2019-03/190306_MERICS-Rhodium\%20Group_ COFDI-Update_2019.pdf , [accessed on: 01.11.2019]

Izdebski M. et al. , Kensbok A., Momot R., Roszkowski M., i in. 2016. Polska wobec inwestorów zagranicznych. Instytut Jagielloński. Warszawa. https:/fundacjarepublikanska.org/wp-content/uploads/2016/11/inwestorzy-zagraniczni-RAPORT-FR.pdf [accessed on: 30.05.2020]

Kupelian. B. 2020. Global Economy Watch. Predictions for 2020: "Slowbalisation" is the new globalisation. PwC. https://www.pwc.com/gx/en/issues/economy/global-economy-watch/assets/pdfs/predictions-2020.pdf [accessed on: 08.07.2020]
Lehnert, K., Benmamoun, M., \& Zhao, H. 2013. FDI Inflow and Human Development: Analysis of FDl's Impact on Host Countries' Social Welfare and Infrastructure. Thunderbird International Business Review, 55(3), 285-298. doi:10.1002/tie.21544 https://doi.org/10.1002/tie.21544

Rozen-Bakher Z. 2017.Impact of inward and outward FDI on employment: the role of strategicasset-seeking FDI, Transnational Corporations Review, DOl: 10.1080/19186444.2017.1290919 https://doi.org/10.1 080/19186444.2017.1290919

Salamaga. M. 2013. Modelowanie wptywu na bezpośrednich inwestycji zagranicznych na handel zagraniczy w świetle wybranych teorii ekonomii na przykładzie krajów Europy Środkowo-Wschodniej. Wydawnictwo Uniwersytetu Ekonomicznego w Krakowie. Kraków.

Treaty on Functioning of European Union, OJC 115/49

UNCTAD. Coronavirus could cut global investment by $40 \%$, new estimates show, https://unctad.org/en/ pages/newsdetails.aspx? OriginalVersion $I \mathrm{D}=2313$ [accessed on: 31.05 .2020$]$

UNCTAD. 2019. World Investment Report 2019. Special Economic Zones. Geneva.

UNCTAD. 2017. World Investment Report 2017. Investment and Digital Economy. Geneva.

Woźniak, M.G. 2008. Wzrost gospodarczy. Podstawy teoretyczne, Wydawnictwo Uniwersytetu Ekonomicznego w Krakowie, Kraków

\section{About the} author

\section{ALEKSANDRA BOROWICZ}

Ph.D. Assistant Professor

Faculty of Economics University of Gdansk

\section{Fields of interests}

Economics and finance.

\section{Address}

Armii Krajowej 119/121, Sopot, PL

E-mail: aleksandra.borowicz@ug.edu.pl 